Katarzyna Łukaszewska

The Maria Grzegorzewska University, Warsaw, Poland

ORCID: 0000-0002-3986-7731

e-mail: klukaszewska@aps.edu.pl

\title{
The Importance of Evaluative Thinking and the Excess of Scientific Effectiveness: Inspirations from Henryk Elzenberg's Thought
}

The fully conscious antagonism: evaluation against scientific cognition, was always central to me.

Henryk Elzenberg (9.07.1954)

\section{Introduction}

The barbarization of science through its exaggerated glorification, especially in its purely theoretical and analytical forms, has been described by Henryk Elzenberg as particularly dangerous in the face of culture. I think the topic is still relevant, and perhaps especially so in the context of the commercialization of science, the marketization of its results, the coefficient nature of parameters for analysing scientific progress, but also in relation to the effects of remote learning and the importance of academic didactics. The pressure of the scientific result, of measurable achievements and quantifiable accomplishments, of the amount of research and its competitiveness - all this results in a strong emphasis, on the one hand, on the importance of science as such, and on the other hand we confront it inevitably with a rather perfunctory way of doing things, devoid of reflexivity. The "psychosis of cognition" so criticized by Elzenberg is reborn, although today in a slightly different climate, and is far too strongly 
associated with professionalism or authentic achievements. Perhaps today we need the intuitive order of the practice of life more than the accuracy and rationalization of pure theory? Maybe the post-pandemic reality demands that we reconsider whether science and knowledge still contribute in any way to the shaping of social competences, and the vision of an isolated university does not foster a false hope that the remoteness of education offers a full-fledged substitute for the intellectual transmission of judgements and opinions... Similarly, like many scholars and educators, I wonder "what the COVID-19 pandemic has revealed (sharpened or illuminated) in the context of the discussion on the contemporary functioning of the university?". ${ }^{1}$ I think that in this perspective, Henryk Elzenberg's observations concerning the extreme dichotomy of pure science on the one hand and culture in its broadest sense (together with its axiological sphere) on the other, become even more significant. I also think that "in the context of the discussion about the contemporary way of functioning of the University, the whole logic of late-capitalist social relations is concentrated" 2 together with a tendency to exaggeration, extremes and all kinds of radicalism; what science is beginning to lack today is humanism or what Elzenberg called culture, i.e. creating things that are valuable, axiologically indifferent and precisely because of this value significant. It is not all the same how we evaluate, let alone that we are capable of making evaluative judgements at all. The problem is that we have depreciated the need for an intuitive search for axiology in favour of analytical precision and research logic, from which it is often impossible to deduce anything that still has some social and cultural value.

Elzenberg said: "the feature that strikes me most in human characters today is the lack of sharp contours, straightforward logic, internal inconsistency $^{\prime \prime 3}$ - and this is by no means the logic of infallible cognition, the precision of a mental construct, from which, apart from intellectual fireworks, nothing special results for the practice of being human. If we recognize that the humanities today suffer from the barbarity of science, it is mainly because it is a science of comparisons and a plebiscite of achievements, of boastful rationality and pure knowledge. In the meantime, however, "it is also important that we actually live in our position, not just persist. To

1 Michał Mokrzan, Marta Songin-Mokrzan, "Fast science, neoliberalne reżimy produktywności oraz technologie ICT: Uniwersytet w czasach pandemii COVID-19", Prace Etnograficzne 48 (2020): 4.

2 Ibidem.

3 Henryk Elzenberg, Kłopot z istnieniem. Aforyzmy w porzadku czasu (Toruń: Wydawnictwo UMK, 2002), 100. 
live it is, above all, to give it expression" ${ }^{4}$ - and what does the fortress of knowledge often give expression to? The triumph of premises, the ability to compose concepts and conclusions? Fineness of thought construction and conceptual precision? We probably need incomparably more today, especially with regard to the ability (shaken by remote work) to develop pro-social competencies and the community dimension of knowledge sharing. "Is the University, which in the time of the pandemic crisis is focused primarily on maintaining (and ultimately - strengthening) productivity indicators, properly implementing its social mission?". ${ }^{5}$ Do we still have this social, communal factor left in science that refers us to the space of culture? Perhaps intuition is an equivalent way of knowing the world, including, above all, the world of values, allowing one to live an axiologically meaningful life and not just "holding one's ground"?

There is something incomparably more important than the purity of a theory and its freedom from evaluative judgements. Increasing the importance of such narrowly defined science at the expense of axiologically important issues is harmful and should be protected from being downplayed. Being is more important than theory, and contributing to the multifaceted world is crucial, especially when it comes to incorporating evaluative thinking into the discourse of scientific achievement. "Such a situation prompts reflection and reference to those philosophers who had already perceived threats to culture in the development of science. Henryk Elzenberg, among others, was such a philosopher"6 (whose axiological sensitivity seems to me to be particularly needed today. After all, knowledge without evaluative thinking has no chance of becoming wisdom. Wisdom, on the other hand, is always linked to good and does not end with intellectual skills.

\section{A civilization turned away from humanity}

"This science-culture antagonism was applied by Elzenberg not only to his understanding of culture, but also to the culture in which we live". ${ }^{7}$ The illegibility of the modern world can be traced back to the breakdown

4 Ibidem, 238.

5 Mokrzan, Songin-Mokrzan, "Fast science, neoliberalne reżimy produktywności oraz technologie ICT: Uniwersytet w czasach pandemii COVID-19": 19.

6 Jan Zubelewicz, "Kultura i nauka: Henryk Elzenberg", in: Wartość i człowiek w 40. rocznicé śmierci Henryka Elzenberga, ed. Wojciech Słomski (Warszawa: Katedra Filozofii Wyższej Szkoły Finansów i Zarządzania w Warszawie, 2007), 36.

7 Ibidem, 43. 
between humanity and civilization, between science and culture, between barbarized knowledge and axiological intuition. Following the observations of Henryk Elzenberg, who criticizes the deification of science at the expense of culture (the ground of which may be unstable but is necessary for the development of all virtue), I see a great potential in value-based thinking, whether in axiology itself or in the intuitive character of ethics. The saturation with commercialized science or marketization of knowledge, in the optics of the dichotomy of truth and falsehood, pushes evaluative thinking to the side, depreciating the intuitive manner of exploring the world, also in the sphere of academic knowledge. Just as pure cognition is a pure illusion, so it is not worth sacrificing the full potential of science to it, taking the occasion to disassociate itself with other aspects of human life, which are becoming less and less the subject of creative analysis. We develop the power of knowledge, the edifice of scientific evidence and the primacy of logic, and we place it above the validity of judgement in the aspect of culture and development, coupled with human capacities in the sphere of goodness, not just rightness. Of course, the blade of Elzenberg's criticism is not directed against science; it "affects [...] a certain considerable fraction of scientists, and also [...] a certain one-sided cult of science" ${ }^{8}$ It is about the prevalence of manifestations of its divinization, being enraptured by its illusory power. This is not a negation of reason or truth; the criticism rather tends "toward an unwarranted pressure to make the space between $[. .$.$] «algebraic» categories of$ truth and falsity a finite and single stage on which humanity takes place". 9 The tasks posed to humanity go far beyond the realm of evidentiality, formal and systemic inquiry: "truth and falsity and the space that these categories construct do not constitute a sufficient basis for anchoring our humanity; they are elements of a description of the human world that are aspectual, fragmentary, incomplete" ${ }^{10}$ There is no basis for chronically elevating their importance to the highest, most significant, comparable and measurable status. The commercialization of science and its marketization is based on a sharp division between factual, scientific analysis and humanistic discourse, reflective and philosophical, and based on axiomatization, intuition and evaluative thinking. In the academic space, this could mean a dichotomy of the roles of researcher-scientist and teach-

8 Henryk Elzenberg, Pisma aksjologiczne, compiled by Lesław Hostyński, Andrzej Lorczyk, Agnieszka Nogal (Lublin: Wydawnictwo UMCS, 2002), 353.

9 Marcin T. Zdrenka, "Tylko prawda? (O Elzenbergowskiej niechęci do 'psychozy poznania')', in: Postacie prawdy, ed. A. Jonkisz, vol. 3 (Katowice: Wydawnictwo Uniwersytetu Śląskiego, 1999), 126.

10 Ibidem. 
er-educator. Unfortunately, this dichotomy is not only real but also promoted: "the realization of the science creation function [...] is given priority over the realization of the educational function. Maintaining the identity of the university requires the realization of both these functions at the same time" ${ }^{11}$ Meanwhile, we not only forget about it, but we value the model of academic work that does not ask itself questions of an axiological nature and does not deal with the connection between the intellect and the good as a value. It should also be added that more and more often we are dealing with a vision of a university that should function as an efficient company, and consequently "research and educational functions, which are inextricably intertwined at the university, remain in a different relationship in an institution providing educational services: the first one is subordinate to the second". ${ }^{12}$ Highlighting strictly scientific achievements in a commercial perspective also exemplifies Elzenberg's concerns - we have become accustomed to depreciating the kind of work that seeks to explore value more than cognition.

I do not wish to convey only a dismal statement of such a reality or a general "aversion to knowledge as knowledge, science as science, truth and falsehood as such, but rather to increase their role beyond essential importance in the hierarchy of human affairs". ${ }^{13}$ In a situation so acutely experienced by all of us, of the exceptional instability of these human affairs, which the COVID-19 pandemic has only sharpened and intensified, this disagreement with the prevalence of the aspirations of science to the level of pure cognition, triumphant certainty, as accurate as it is unwieldy, seems today to be an attempt to turn our gaze, also scientific, towards the broadly understood humanities. These tendencies are perhaps expressed "among others by the intellectual movement known as Slow Science, which in this context seems [...] particularly worthy of interest", ${ }^{14}$ mainly due to the fact that, after all, we are increasingly accepting the fact that "there are no silver medals in science, so the competition is fierce". ${ }^{15}$ "As the authors of The Slow Science Manifesto (2010) point out: 'Science

11 Ewa Skibińska, “Nauczyciel akademicki w sytuacji urynkowienia edukacji wyższej", in: Rynek i kultura neoliberalna a edukacja, ed. A. Kargulowa et al. (Kraków: Oficyna Wydawnicza Impuls, 2005), 211.

12 Agnieszka Lekka Kowalik, “Uniwersytet jako firma usługowa. Szansa czy klęska?", Ethos 85-86 (1-2) (2009): 62.

13 Zdrenka, "Tylko prawda? (O Elzenbergowskiej niechęci do 'psychozy poznania')", 126.

14 Mokrzan, Songin-Mokrzan, "Fast science, neoliberalne reżimy produktywności oraz technologie ICT: Uniwersytet w czasach pandemii COVID-19": 17-18.

15 Lekka-Kowalik, “Uniwersytet jako firma usługowa. Szansa czy klęska?”: 65. 
needs time to think. Science needs time to read and time to make mistakes. Science does not always know what is currently happening [...]. We need time to think. We need time to digest our thoughts"'. ${ }^{16}$ We do not get wiser the more we know, but when we try to understand together: the university "as an organization evolved ... from a community to an enterprise", 17 and therefore there are, I think, many more of these dichotomies inspired by Elzenberg's suggestions. We have a hard time admitting that evaluative thinking is necessary for us to be human, and when we ignore knowledge in the field of values, we want to rely only on the theory that will explain the world to us best and determine all rightness without referring to axiology. Meanwhile, we increasingly try to meet demands diluted by elusiveness and clarifying our tasks in terms of only blurred meanings, changing references, unpredictable events and their scale. If, as Elzenberg warned, we intensify our perception of the world through the prism of pure science, civilization will simultaneously turn its back on humanity; let us not be afraid to admit that axiology is the basis for the acquisition of knowledge - if we lack it, if we devalue it completely, what we will be left with is a robotic tendency towards rigorous analysis, the conclusion of which we will no longer be able to bear, either as men of science, men of culture, or society in general.

\section{The cult of science versus the creation of culture}

The problem is not the rank of science, but the saturation of its relevance, the eminence of theoretical precision. "The term science or scientific has become a fetish in Elzenberg's understanding. Science is generally considered to be the most important factor, the very core of culture", ${ }^{18}$ while the culture-creating part of science disappears when we allow it to be radicalized, made more sophisticated, cut off from the imprecise axiology and the evaluative way of thinking. It is true that science plays a large role in culture and it is not legitimate to question this position, nevertheless, "it is quite common to see only the constructive side of science, while

16 Mokrzan, Songin-Mokrzan, "Fast science, neoliberalne reżimy produktywności oraz technologie ICT: Uniwersytet w czasach pandemii COVID-19": 17-18. Cf. www.slow-science.org.

17 Skibińska, "Nauczyciel akademicki w sytuacji urynkowienia edukacji wyższej", 213.

18 Zubelewicz, "Kultura i nauka: Henryk Elzenberg”, 38. 
questioning its destructiveness", ${ }^{19}$ which can be really dangerous, especially in its allergic detachment from human reality and its specific, not theoretical problems. Science, for all its theoretical speculation and intellectual fireworks, remains axiologically empty; it advances the edifice of a hegemonic deity of technical knowledge, free from valuation, from questions of meaning and significance in the context of a world of values. "Limiting research to collecting data to verify hypotheses implies a reductive view of science. The spirit of such research in didactics was subjected to a crushing criticism by Zaczyński, who argued that it ignores the specificity of the scientific nature of didactics and its research methods. And transferring the principles of scientism to the didactic field brings at best sterile if not destructive results".$^{20}$ The hypothetical possibilities of analytical discourses often take precedence over common sense and foster the creation of extreme oppositions. Therefore, "Elzenberg strongly rejected the scientific worldview in its radical version. He did not accord the highest rank in his axiology and culture to science, cognition or truth" ${ }^{21}$ The multifaceted nature of the world was more convincing to Elzenberg than the hegemony of cognition, which is the deification of the given; he was put off by forcing the formalism of science within the scope of potential creativity, without the participation of values. This sharp separation may also signify a disjunction between pure theory and the practical search for meaning in axiological space. What creates culture, creativity, meaning - has a value far greater than theoretical rational prowess. "Methodological fundamentalism [...] excludes, through seemingly neutral standards of scientism, the practices of evaluation of scientific work, of universal measurability of scientific activity, of socially engaged knowledge. It reduces research to a form that is servile to the status quo by, among other things, stunting critical thinking and ethical concern for the common good".22

Like Elzenberg, "by culture I mean the sum of things that can be created by man and that are of value". Moreover, the key here will be Elzenberg's concept of value as something "independent both of us and the relation between us and the object, something that would be in the object even if it

19 Ibidem, 35.

20 Maksymilian Chutorański, Oskar Szwabowski, “Parametryzacja, humanistyka i los mieszkańców Rapa Nui", Rocznik Lubuski 44, part 2 (2018): 150. Cf. Władysław Piotr Zaczyński, Metodologiczna tożsamość dydaktyki (Warszawa: Wydawnictwa Szkolne i Pedagogiczne, 1988).

21 Zubelewicz, "Kultura i nauka: Henryk Elzenberg", 41.

22 Chutorański, Szwabowski, "Parametryzacja, humanistyka i los mieszkańców Rapa Nui": 151. 
existed alone in the world". ${ }^{23}$ This perfect way to grasp value, so characteristic of Elzenberg, allows us to understand the enthusiasm in defending its meaning - it is a full-fledged, culture-creating space, fully meaningful. "No goal for the attainment of which valuation is necessary can be attained by the means of science alone". ${ }^{24}$ We need evaluative thinking as much as scientific thinking, because opinion, judgement, axiological inference, brings value into the world of science, and that is the right place for it. "Cognition should not be the highest rank in the hierarchy of human activity", ${ }^{25}$ for we are much more capable in the field of valuations. Able and obliged at the same time, because "if we avoid creating culture, there will be no culture: no one will bring it out of non-existence for us" ${ }^{26}$ When we adhere to science alone, we not only strip creativity of its axiological sense, but turn our backs on culture, which is not only an antidote to scientific satiety or a break from insight. "Culture is neither recreation nor entertainment. It is an intrinsic and serious reality; it is not a way of spending time, not a means of regeneration. It is the great human realm of values in which man becomes a fuller human being". 27 The edifice of knowledge and the cult of science "is insufficient $[\ldots]$ to ground cultures, and [...] its finest development could coexist with barbarism" 28 and this is very much the crux of the problem - we may not even notice when scientific progress does not mean human development at all. If we recognize that in some sense civilization is turning its back on man, it is mainly because of its inability to ground culture in pure science alone.

What we are experiencing is "the hegemony of science in culture. A fatal domination for culture", 29 as Elzenberg noted, but this hegemony is still very relevant today: it is the primacy of scientific inquiry over its validity and the dehumanization of knowledge in favor of result and outcome, both in educational communication and in scientific research. Moreover, "a kind of religion of science has emerged and, against all resistance, is generally developing and spreading", 30 which, in the context of such activities as continuous evaluation, parameterization or commercialization

23 Elzenberg, Pisma aksjologiczne, 354.

24 Ibidem, 358.

25 Zdrenka, “Tylko prawda? (O Elzenbergowskiej niechęci do 'psychozy poznania')", 131.

26 Elzenberg, Pisma aksjologiczne, 355-356.

27 Bogdan Suchodolski, Wychowanie i strategia życia (Warszawa: Wydawnictwa Szkolne i Pedagogiczne, 1983), 65.

28 Elzenberg, Pisma aksjologiczne, 358.

29 Ibidem, 361.

30 Ibidem. 
of science sounds, in my opinion, particularly strong. "With regard to the changes that the University in Poland has undergone in the last decade, the characteristic instruments [...] include activities such as: quantification of scientific achievements, algorithmization of the quality of research work, parameterization of universities, granting accreditation through mutual control and audit". ${ }^{31}$ The university is increasingly expected to produce knowledge rather than share it; "British anthropologists have begun to speak of emerging ... 'cultures of audit', which Marylin Strathern describes as 'cultures of management and accountability"'. ${ }^{32}$ Academic discussion, which asks for meaning, not just logical truth, is thus replaced by an effort to shape institutions into research institutes, where the cult of science is disproportionate to its actual contribution to culture. We also forget that "science is too weak to build culture on its own". ${ }^{33}$ For it is not the case that human activity has its culmination in the form of knowledge, science and cognition; however, if we move away from evaluative humanism, capable of moral conclusions, giving opinions in the categories of good and evil, then this "suppression of evaluating oneself leads many scholars to condemn it unconditionally". ${ }^{34}$ We depreciate axiological depth in favour of a delight in "citability" or "indexability". Our focus is, by all means, on the measurability of scholarly achievements, and we grant them the right to witness the importance of all activities in the field of university tasks. Opinions about creativity are made by means of comparative scales, looking for indicators and conversion rates, rarely concerned with axiological or ethical validity. The excess of science, so criticized by Elzenberg, takes on a new dimension in our times - it is the disproportion between the scientific pursuit of the best possible result and the ability to value the meaning of this pursuit. So perhaps there is still a chance to wake us from "yet another "dogmatic nap". And perhaps it will serve as a warning - to paraphrase Putnam's saying - against practicing the worst kind of 'armchair' philosophy of science: a priori philosophy". ${ }^{35}$

"None of the reasons for renouncing evaluation argues for despising $\mathrm{it}^{\prime \prime},{ }^{36}$ yet culture and the humanities, broadly defined, suffer most today

31 Mokrzan, Songin-Mokrzan, "Fast science, neoliberalne reżimy produktywności oraz technologie ICT: Uniwersytet w czasach pandemii COVID-19": 11.

32 Ibidem: 251.

33 Zdrenka, "Tylko prawda? (O Elzenbergowskiej niechęci do 'psychozy poznania")", 129-130.

34 Elzenberg, Pisma aksjologiczne, 359.

35 Agnieszka Lekka-Kowalik, “Dlaczego nauka nie może być wolna od wartości", Roczniki Filozoficzne 52, no. 2 (2004): 292.

36 Elzenberg, Pisma aksjologiczne, 359. 
from a contemptuous attitude toward their own creations and attempts to seek answers using evaluative thinking. Of course, it is not a question of despising science either, but only of equal status: axiology, culture, and valuing are at the heart of development, and strenuously opposing them to science is definitely unfounded. In a reality that poses more and more questions than scientific knowledge can answer, intuitive evaluative judgements remain, as one might think, an increasingly urgent necessity and a chance to overcome the stubbornness of an often powerless science. But how about agreeing that seeking the good is a more urgent need than seeking even deeper knowledge, even more illustrious knowledge? Let us try to "accept the risk, accept that perhaps we are building on air and we are erecting an edifice of delusion on a foundation of delusion", 37 which does not necessarily mean that this effort is futile, since it helps to explain the world from the perspective of questions about meaning and value, and not only truth and cognition. The concern about the place of axiology in science and the importance of value judgement for the meaning of any inquiry is, I believe, caused by the conviction of the harmful influence of the hermetic character of pure knowledge both for its creators and for the space which should have a culture-creating connection with this very science. Scientific inquiry loses its dignity without the intention of being part of the broader culture - only man creates culture, and nothing will distinguish him from other breathing creatures if he abandons creativity for efficiency. To be aware of that in the dimension of science, as well as in any other, is "a sacred duty of every conscious co-creator of culture, as well as his dignity and virtue. [...] A virtue, we might add, which sharply contrasts it with the type personified in the scientist", 38 who more or less consciously participates in an absurd race for the laurels of scientific leadership in research work, which has absolutely no communal character; the adoration of science alone and its possibilities creates rather a tendency to focus on oneself. Firstly, because "it is human nature that everyone wants to monopolize respect and all benefits for oneself. Therefore, is it any wonder that whoever practices an activity that is discursive in some part of its nature, tries to emphasize this discursiveness, i.e. scientificity, and to ensure for themselves the talisman of 'scientificity"'? ${ }^{39}$ Thus, the cult of science often excludes the ability to co-create culture, monopolizing and privatizing achievements that do not seek answers to socially pressing

37 Ibidem, 356.

38 Ibidem.

39 Cf. Henryk Elzenberg, "O 'wąskim' pojmowaniu nauki”, in: Materiały Henryka Elzenberga, PAN Archives, file 50. 
questions: selectively and separatively - this is largely the effectiveness of scientific discussions, not only incompatible with many other areas of culture, but even sharply antagonized with them. Thus, we forget that "if science is not combined with additional supra-life values, it is then, to some extent, at war with the rest of culture". ${ }^{40}$ The cult of scientism is axiologically harmful, it squanders the multitude of culture-creating opportunities for evaluative thinking, defining priorities, ordering reality with meanings and sense. The fact that truth is primarily a value is more important than that it enables scientific integrity. Admiration for the intellect should be confronted with appreciation for wisdom, which has a moral value. When we are able to share value with people, we co-create an axiologically accessible, egalitarian, and comprehensible reality; when we rise to the heights of purely scientific knowledge, we elevate our own intellectual status to a level not of moral virtue but of theoretical possibility. Therefore, without reflection on values, we will continue to build ever more sublime and individualized pedestals of personal potential which, erected in the name of science, do not necessarily remain communicable, though they are entirely content with their own status. Evaluative thinking seeks meanings and axiological structures in knowing the world. Science that does not ask about value, including the value of itself, it closes itself and brings contempt for any other activity that differs from its methods and capabilities. Meanwhile, we are as human beings obliged to an activity far beyond theoretical prowess, beyond pure knowledge and cognition; thinking that values, compares, seeks reference is elementary and cannot be reduced to the level of mere confrontation. What is at stake here is a kind of "elemental fact of valuation", ${ }^{11}$, a fact that, although different from the scientific one, remains full-fledged in terms of meaning.

40 Zubelewicz, "Kultura i nauka: Henryk Elzenberg”, 43.

41 Cf. Elzenberg, PAN Archives, file 50. 


\section{The meaning of evaluative thinking}

In my opinion, the appreciation of the importance of evaluative thinking 42 is based primarily on the disturbing observation that "scientists are in the process of replacing evaluative thinking by scientific thinking". ${ }^{43}$ This confrontation almost always ends to the detriment of axiology as a science, which, after all, seeks to develop particularly meaningful practical insights from the analysis of values. However, the problem is not only that science is somehow afraid of axiology, but also that "the scientist [...] according to Elzenberg, tries to impose his prejudices against axiology on his surroundings. Thus, he convinces others not to evaluate at all, or - if they do - not to take their evaluations seriously". ${ }^{44}$ After all, what concrete results can come from evaluative thinking? Even Henryk Elzenberg himself considered cognition of value to be intuitive: "intuition lies at the basis of valuing", ${ }^{45}$ and it is hard to deny this. Even more, "intuitionism has accompanied ethics since its birth as a philosophical issue. We find out about the impossibility of building ethics (and probably in general - axiology) using the analytical-deductive method on the basis of studies on the ethics of Aristotle, who, after all, in moments of complication of purely rational ways of shaping ethical knowledge points to the role of experience and moral intuition". ${ }^{46}$ Thinking about values is a self-educative process that requires practice, training, and "the ability to relate facts to values is acquired through - usually long - hands-on learning. This may be termed as 'ethical terming"', ${ }^{47}$ which corresponds to the importance of the formation of ethical virtue in man: "Aristotle said that he who is not ethically brave cannot know what is good" ${ }^{48}$ Knowledge alone is not enough, I may be wrong in my thought, but I should not be wrong in my being. "This is why the outward act is not accidental, but an organic outflow from the

42 I recognize a significant difference between evaluating and evaluative judgements, but for the purposes of this text, I use the two terms interchangeably; "evaluative thinking" is, for many reasons, a closer term to me, but Elzenberg's (and others') term "evaluation" appears above all as confronted with pure scientific cognition.

43 Zubelewicz, "Kultura i nauka: Henryk Elzenberg”, 45.

44 Ibidem, 46.

45 Elzenberg, Pisma aksjologiczne, 357.

46 Ryszard Wiśniewski, "Na marginesie aksjologii Henryka Elzenberga", Acta Universitatis Nicolai Copernici. Nauki Humanistyczno-Społeczne. Filozofia 12 (228) (1991): 40.

47 Kazimierz Szewczyk, Wychować człowieka mądrego. Zarys etyki nauczycielskiej (Warszawa: Wydawnictwo Naukowe PWN, 1999), 38.

48 Wiśniewski, "Na marginesie aksjologii Henryka Elzenberga": 41. 
righteous man being just". ${ }^{49}$ For in the domain of evaluative, culture-creating thinking, "evil does not consist in the fact that one lives according to some 'false' moral convictions, but in the fact that one lives essentially immorally. The choice he made was not between truth and falsehood, but good and evil"..$^{50}$ The importance of valuations in human life is not based on the precision of scientific inquiry, and this is as intuitive as it is necessary and urgent today. Furthermore, let us remember that "intuition is also cognition", 51 and that cognition itself has much in common with instinct, intuition, and the impulse of the heart. As Løgtsrup notes, even the question of morality and its validity can mean the end of morality, because in ethical action there is much more going on at the level of spontaneity than later reflection; ${ }^{52}$ it is value that adds meaning - but one must in some way be captivated by value, let oneself be enthusiastically blinded by its charm.

"If we assume that there are two mindsets of thought: "evaluative" for evaluative thinking and "rational-logical" ("purely cognitive") for scientific thinking, $[\ldots]$ then in the process of undertaking research it is advisable, if not essential, to exclude or dismiss the inadequate attitude. If the thinker turns their interest to science, they suppress - as methodologically inadequate - the evaluative attitude. There is nothing wrong with this as long as [...] a general principle is drawn, which reads: since evaluative thinking interferes with scientific thinking, it should not only be avoided during scientific research, but it should be eliminated altogether from the thinking activity of rational man". ${ }^{53}$ However, "to understand the possibility of conflicts between scientific thinking and evaluative thinking, one must first realize that these are really two different, self-contained forms of thinking". ${ }^{54}$ In juxtaposition, opposed, they do great harm both by ruining evaluative judgements and by exaggerating the importance and validity of pure scientific thinking. By not allowing axiology to enter the realm of science devalues its significance and distances it from the reality of what is being created; for although "evaluative" thinking is in-

49 Józef Piórczyński, Mistrz Eckhart - Mistyka jako filozofia (Wrocław: FNP, 1997), 252.

50 Jacek Filek, Filozofia jako etyka (Kraków: Znak, 2001), 185.

51 Zdrenka, "Tylko prawda? (O Elzenbergowskiej niechęci do 'psychozy poznania')", 135.

52 Por. Knud Ejler Løgtsrup, After the Ethical Demand, transl. S. Dew, M. van Kooten (Århus: University Press, 2002).

53 Zdrenka, "Tylko prawda? (O Elzenbergowskiej niechęci do 'psychozy poznania')", 130.

54 Elzenberg, Pisma aksjologiczne, 357. 
herently opposed to "scientific" thinking,, 5 the abandonment of evaluative judgements promotes creation for creation's sake. After all, "one cannot consciously create things of value without making appropriate "evaluative" judgements" ${ }^{56}$ It seems reasonable to ask, then: how valuable is pure cognition? Doesn't such exclusion eliminate ourselves, every researcher? "By negating the sphere of judgements and evaluation [...] by reducing them to 'scientific' categories, the researcher condemns themselves to banishment to the land of schemes, structures, and dead representations subordinated to a single criterion: truthfulness and falsity" ${ }^{57}$ This banishment is the result of an aversion to evaluation and uncertainty about value as such; the full value of scientific validity and accountability is not contained within the structures of truth and falsity. We forget that, however difficult in their intuitive cognition, "values are [...] facts revealing themselves to us in judgements, in a peculiar way of experiencing the world", 58 they remain recognizable and characteristic of man's way of being. Value is not a myth, it is an important and permanent part of our reality - to escape from value into pure cognition is ignorance for fear of axiological intuition. Yet, "the rejection of a subjective or evaluative thread in thinking is wrong because it supports an argument that unconsciously uses one of the rejected elements" 59 - after all, "a negative evaluation of evaluative thinking also leads to a discrediting of a positive evaluation of scientific thinking, since the belief in the value of scientific thinking is - as an evaluative judgement - equally subjective and impossible to justify in an intersubjective way". ${ }^{60}$ Therefore, if I think something is inferior, I do so by virtue of an evaluative judgement. Nevertheless, "this disbelief in the scale of values has already become part of our blood", 61 and this also applies to axiological inquiry itself. "As long as axiologists attempt to grasp values theoretically [...], it will be ineffective, and axiology will suffer from theorism". ${ }^{62}$ I think, however, that the "theorizing-evaluating" opposition

55 Zdrenka, “Tylko prawda? (O Elzenbergowskiej niechęci do 'psychozy poznania')", 129.

56 Elzenberg, Pisma aksjologiczne, 356.

57 Zdrenka, “Tylko prawda? (O Elzenbergowskiej niechęci do 'psychozy poznania')", 131-132.

58 Wiśniewski, "Na marginesie aksjologii Henryka Elzenberga": 33.

59 Zdrenka, "Tylko prawda? (O Elzenbergowskiej niechęci do 'psychozy poznania')", 131.

60 Lekka-Kowalik, “Uniwersytet jako firma usługowa. Szansa czy klęska?”: 61.

61 Elzenberg, Pisma aksjologiczne, 361.

62 Andrzej Niemczuk, "Diagnoza i terapia aksjologii”, in: Aksjologia współczesności. Problemy i kontrowersje, ed. Bogumiła Truchlińska (Lublin: Wydawnictwo UMCS, 2012), 32. 
is an understatement of the problem that really lies in the role of evaluative judgements in general, and the role of evaluative judgements in science in particular: it is "an opposition to the view, characteristic of contemporary ethics, that it is possible to set up signposts without the need to practice the designated path". ${ }^{63}$ It seems to us that we can do science without being involved in culture; that it is possible to build a scientific edifice without the use of evaluative judgements and without having to immerse ourselves in any social discourse. We forget that "evaluative thinking involves value, while value is the foundation of culture, which is a much broader concept than science". ${ }^{64}$ It may turn out that we build for the sake of building, we create for the sake of theory, and meticulous analysis brings us nothing new but reliability, accuracy, precision, scientific calibration... "I would not give half a penny for a life devoted to pure cognition," Elzenberg said in The Trouble with Existence, "and I wish that others would not give their whole souls for it".65

\section{Conclusion}

"The man of science is afraid of valuation", 66 because it blurs the image of crystal clear knowledge, which alone is supposed to be capable of providing a measurable criterion of progress and a measure of achievement. "Blindness to values, which is a heroic sacrifice of people of pure knowledge, has also affected, in this sphere, a significant part of the community", 67 including the academic community, more and more focused on the measurability of humanities and the quantifiability of its scientific results. This is not only harmful, it is morally non-neutral because of the effects it has: "the condemnation of evaluative thinking by scientists and the hegemony of science in culture, according to Elzenberg, lead to havoc in other areas of culture" ${ }^{68}$ It is not indifferent when we accept the primacy of form, scheme, pure analysis. We succumb to the pressure to multiply what is scientific, clear, measurable. The truth about cognition, however, is different - "It is not in the capacity of human cognition that the strength

63 Wiśniewski, “Na marginesie aksjologii Henryka Elzenberga": 41.

64 Zdrenka, "Tylko prawda? (O Elzenbergowskiej niechęci do 'psychozy poznania')", 129.

65 Elzenberg, Kłopot $z$ istnieniem. Aforyzmy w porzadku czasu, 173.

66 Zubelewicz, "Kultura i nauka: Henryk Elzenberg", 45.

67 Elzenberg, Pisma aksjologiczne, 362.

68 Zubelewicz, "Kultura i nauka: Henryk Elzenberg”, 47. 
lies, [...], but in the very fact, in the very ability to know and, what was particularly important for Elzenberg, to judge. We can hesitate and doubt, but we can also always admit it to ourselves. Thinking is our dignity", ${ }^{6}$, let us not give it up for the glory of precision. We need evaluative thinking not to construct models, but to develop creativity and co-create culture. Barbara Skarga once put it in a similar way: "Analysts are looking for strict definitions and logical connections between concepts. I'm fascinated by the historical variability of meaning and the variability of thought as such, and what remains permanent in it. When one examines human thought from this point of view, certain problems can be discovered in it, which are repeated in different variations. One of these problems is the search for truth, [but] also the search for value, for good $[\ldots]^{\prime \prime},{ }^{70}$ which does not allow us to stop at mere cognition. I think we lose good and value by risking their fate in the struggle to arrive at irrefutable certainty, scientific accuracy. Elzenberg warned us against the glorification of truth at the expense of values, because of the sense-creating power inherent in undertaking the effort of evaluative thinking. It is all the more difficult to conclude that "we see people who, despite all the obvious impossibility, try to keep up, try to race with production, keep track of everything and "want to know" everything. Such an attitude is disastrous as it turns creations, whose whole human meaning consists in being absorbed [...], drunk as wine, into objects of naked cognition, - which means the end of culture". ${ }^{71}$ Creativity, including scientific creativity, ceases to contribute to culture when it begins to ignore evaluative thinking, which we will either come to prove - or experience.

\section{Bibliography}

Chutorański Maksymilian, Szwabowski Oskar. 2018. “Parametryzacja, humanistyka i los mieszkańców Rapa Nui”. Rocznik Lubuski 44, cz. 2: 145-163.

Elzenberg Henryk. “O ‘wąskim' pojmowaniu nauki”. In: Materiały Henryka Elzenberga, Archiwum PAN, teczka 50.

Elzenberg Henryk. 2002. Kłopot z istnieniem. Aforyzmy w porzadku czasu. Toruń: Wydawnictwo UMK.

69 Tomasz Mazur, Zbawienie przez filozofię. Interpretacja twórczości Henryka Elzenberga (Warszawa: Wydział Filozofii i Socjologii Uniwersytetu Warszawskiego, 2004), 156.

70 Barbara Skarga, Pisma rozproszone z lat 1989-2000, ed. Marcin Pańków (Warszawa: SENATOR, 2015), 140.

71 Elzenberg, Kłopot z istnieniem. Aforyzmy w porzadku czasu, 171. 
Elzenberg Henryk. 2002. Pisma aksjologiczne, compiled by Lesław Hostyński, Andrzej Lorczyk, Agnieszka Nogal. Lublin: Wydawnictwo UMCS.

Filek Jacek. 2001. Filozofia jako etyka. Kraków: Znak.

Lekka-Kowalik Agnieszka. 2004. “Dlaczego nauka nie może być wolna od wartości". Roczniki Filozoficzne 52, no. 2: 275-293.

Lekka-Kowalik Agnieszka. 2009. “Uniwersytet jako firma usługowa. Szansa czy klęska?". Ethos 85-86 (1-2): 52-69.

Løgtsrup Knud Ejler. 2002. After the Ethical Demand, transl. Susan Dew, Niekerk van Kooten. Århus: University Press.

Mazur Tomasz. 2004. Zbawienie przez filozofię. Interpretacja twórczości Henryka Elzenberga. Warszawa: Wydział Filozofii i Socjologii Uniwersytetu Warszawskiego.

Mokrzan Michał, Songin-Mokrzan Marta. 2020. “Fast science, neoliberalne reżimy produktywności oraz technologie ICT: Uniwersytet w czasach pandemii COVID-19". Prace Etnograficzne 48: 1-21.

Niemczuk Andrzej. 2012. “Diagnoza i terapia aksjologii”. In: Aksjologia współczesności. Problemy i kontrowersje, ed. Bogumiła Truchlińska, 27-35. Lublin: Wydawnictwo UMCS.

Piórczyński Józef. 1997. Mistrz Eckhart-Mistyka jako filozofia. Wrocław: FNP.

Skarga Barbara. 2015. Pisma rozproszone z lat 1989-2000, ed. Marcin Pańków. Warszawa: SENATOR.

Skibińska Ewa. 2005. “Nauczyciel akademicki w sytuacji urynkowienia edukacji wyższej". In: Rynek i kultura neoliberalna a edukacja, ed. Alicja Kargulowa, Stefan M. Kwiatkowski, Tomasz Szkudlarek, 211-221. Kraków: Oficyna Wydawnicza Impuls.

Songin-Mokrzan Marta. 2016. “Transformacja uniwersytetu. 'Kultury audytu' i neoliberalne technologie zarządzania podmiotami społecznymi”. Kultura i Edukacja 3 (113): 242-257.

Suchodolski Bogdan. 1983. Wychowanie i strategia życia. Warszawa: Wydawnictwa Szkolne i Pedagogiczne.

Szewczyk Kazimierz. 1999. Wychować człowieka mąrego. Zarys etyki nauczycielskiej. Warszawa: Wydawnictwo Naukowe PWN.

Wiśniewski Ryszard. 1991. "Na marginesie aksjologii Henryka Elzenberga”. Acta Universitatis Nicolai Copernici. Nauki Humanistyczno-Społeczne. Filozofia 12 (228): 29-42.

Zaczyński Władysław Piotr. 1988. Metodologiczna tożsamość dydaktyki. Warszawa: Wydawnictwa Szkolne i Pedagogiczne.

Zdrenka Marcin T. 1999. "Tylko prawda? (O Elzenbergowskiej niechęci do 'psychozy poznania')". In: Postacie prawdy, vol. 3, ed. Adam Jonkisz, 125-137. Katowice: Wydawnictwo Uniwersytetu Śląskiego.

Zubelewicz Jan. 2007. “Kultura i nauka: Henryk Elzenberg”. In: Wartość $i$ człowiek w 40. rocznice śmierci Henryka Elzenberga, ed. Wojciech Słomski, 35-50. Warszawa: Katedra Filozofii Wyższej Szkoły Finansów i Zarządzania w Warszawie. 


\section{Summary}

The dynamics of changes in science inevitably, but also increasingly urgently begins to include ethical reflection. These issues include such problems as: the gap between the prestige of scientific and didactic activity, building scientific achievements solely through the prism of their carrying capacity, or the lack of influence of science on social and cultural life. The dominant role in shaping teaching standards is played by such phenomena as parameterization, indexing, coefficients or accreditation, while the normative space of scientific activity is no longer subject to such obvious standardization. The educational and cultural role of the people of science devalues towards entrepreneurship and effectiveness. Based on Henryk Elzenberg's views on the excess of the importance of science to the detriment of evaluative thinking, it can be noted that contemporary academic expertise does not seem to pursue any axiological connotations, which in the long run is a highly disturbing advantage for culture.

Keywords: science, culture, Henryk Elzenberg, axiology, evaluative thinking 